\title{
6 \\ Invulnerability and protecting the sovereign body
}

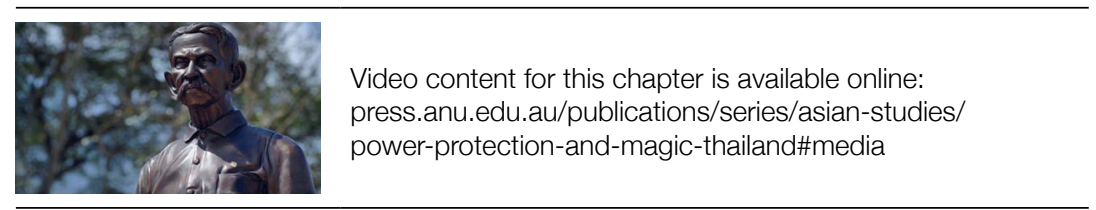

Khun Phan's dealings with bureaucrats in the capital, his police contacts in other provinces and his encounter with villagers and officials in many parts of the country yield a story that transcends the local or the regional. The social world of place, religion, policing and banditry he inhabited as he moved from post to post and town to town breaks down the distinctions between local, regional and national that bedevil the entrenched categories that fragment writing about Thailand's past. The narrative of Khun Phan's life tells the story of a country boy who succeeded wherever he was posted and who made a name for himself in the police force-an institution that has dominated Thai political culture since World War II.

Yet Khun Phan's deeds in the field are not what commend the policeman's story for consideration to better understand law and order in the Thai countryside in the first half of the twentieth century. Rather, it is invulnerability, both personal and institutional, that preoccupied him from his adolescent years through his career in the police force as he planned and executed his operations in the pursuit of outlaws. For Khun Phan's personal protection, the therapies and dietary regimens in the saiyasat repertoire kept his body healthy and free from disease. His daily supplications and ritual bath aimed to deflect or neutralise whatever might befall him in the course of his duties if he breached religious tenets against 
taking human life, and he did breach those tenets on many occasions. From his first serious encounter with the outlaw Suea Sang, whom he killed in 1930, Khun Phan was made aware of his own vulnerability and the precarity of police life.

The anthropologist Andrew Turton once proposed that ideas and practices of invulnerability were forms of knowledge that served as strategic moves employed by the weak, the powerless and the disenfranchised. These ideas of invulnerability coexist with powers of bilocation, metamorphosis, becoming very small, hiding, invisibility, masking, disguising, anonymity and pseudonymity. Such strategic moves enable the person employing them to elude or resist authority. Turton—adopting and adapting models of power relations from Louis Althusser, Antonio Gramsci, Maurice Bloch and British Marxist social scientists-went on to suggest that intimidation and surveillance were instrumental in the exercise of power, while their opposites, invulnerability and invisibility, were valuable to underground leaders and subaltern insurgents who worry established authority with their threats of popular mobilisation and uprising (Turton 1991: 164, 176). While the context of Turton's discussion hardly corresponds with the southern policeman's operations in the Thai countryside, his insight is a stepping-stone to further inquiry into how these binaries function.

As Khun Phan's story demonstrates, and as Turton's discussion implicitly acknowledges, invulnerability and invisibility are available not only to the weak but also to state institutions. Turton illustrates powers of invulnerability combined with powers of invisibility, disguise, escape, personal charm and the ability to render one's foes immobile by pointing to a character in the Thai epic poem Khun Chang Khun Phaen. This character, Khun Phaen-not to be confused with Khun Phan, the southern policeman - is no ordinary foot soldier but a senior military commander in the service of the king. Considering the period of the epic poem, which is mostly the eighteenth and nineteenth centuries, we can speak not of the state and its institutions but of a kingdom, a king and military officers, all of whom were at the apex of the social and political hierarchy. The character Khun Phaen in the poem was not among the weak and the powerless, but an officer in that hierarchy, yet the nimble strategies to which he resorted were no different from those available to the subaltern classes. 
Police officers in Khun Phan's time knew these strategies well. Khun Phan himself occasionally worked incognito, as did Luang Adul, the national police chief during World War II who wore civilian clothes during his night patrols to appear non-threatening and to conceal his official identity. Khun Phan once disguised himself as a railway worker in Phatthalung to ferret out thieves. On another occasion, the southern policeman, disguised as a Chinese hawker shouldering baskets of chickens at the ends of a carrying pole, was spotted by an alert villager returning from his garden, who shouted to his son: 'There, there goes Khun Phan!' The villager may have erred in his identification-perhaps it was someone who resembled the policeman-but that is the point of disguise. Khun Phan could be anywhere and everywhere in the mode of all-seeing police who, when it suits them, choose not to be seen. Maintaining law and order involves the optic of rule.

Government does its work not only by legislating, providing services and maintaining law and order using its monopoly over the use of violent force, but also by watching, recording and knowing where everything is located. Nowadays the optic necessary to government is centralised thanks to digital technology and is diffused through society in handheld electronic devices - a development that worries citizens everywhere. In premodern Siam, the optic of monarchical rule operated-apart from tax collectors, spies and other informants-through ceremony and royal progress. The king and his entourage would occasionally venture out of the royal base into the nearby countryside. He would be able to see for himself, to the extent he was curious, the benefits and munificence of his rule; equally important, he could be seen by at least some of his subjects. In the 1950s, early in the reign of the ninth Bangkok monarch when the elite was still reeling from the tragic 1946 death of the king's brother in the royal bed chamber, King Bhumibol visited many provinces in the kingdom and subsequently built palaces in the north, the northeast and the south. Over the many decades of his reign, he travelled widely around the country with a camera and maps in hand. This activist monarch, who was constrained by the Thai constitution to reign only but not to rule, reinvented the royal progress to bind himself to his subjects using photography and cartography-tell-tale instruments of the optic of rule.

1 Akhom Dechathongkham (1949-2016), Personal communication, 22 September 2009; and Akhom (2001: 209). 
He also took his sacral duties seriously and availed himself of the iconography of the sacred image that allowed him to be, miraculously, omnipresent. Over three days in late August 1965, a royal Buddha image was cast at Wat Bowonniwet in Bangkok, the royal monastery where Prince Mongkut had been abbot and where King Bhumibol had been ordained. The image was similar in its iconography and morphology to one cast in Kanchanaburi in 1963 to commemorate a visit by the king when he turned 36, his third-cycle birthday and an occasion to be celebrated in a special way. Kanchanaburi was the birth province of Phra Nyanasamvara, who was to serve as the king's spiritual adviser and who became supreme patriarch in his later years, until his death in 2013. All Buddha images are copies of a previous image - reminders of the Buddha—but the copies are never exact, as they are subject to the constraints of different materials (bronze, terracotta, timber, crystal, stucco), to the different skills of sculptors and to the tastes of patrons who commission the images. The 1965 royal Buddha image was different from the 1963 Buddha in one important respect. On its base was inscribed 'nation, religion, and monarchy' — words that conveyed a political message.

The timing was not happenstance, for earlier in August 1965 an armed conflict between the army and the CPT erupted, which the communists declared later to be the onset of a people's war against the Thai Government (Morrell and Chai-anan 1981: 81-2). The Second Indochina War that would draw the United States into a bloody conflict in Vietnam, Cambodia and Laos was just beginning and, from air bases in Thailand, which served as a loyal US ally in the prosecution of the anticommunist campaigns in the region, American warplanes would take off to carpet-bomb targets in the neighbouring countries. The 'political message' of the amulet, in the words of Natthaphon Yurungrueangsak (2012: 108-11) in his history of Thailand through Buddha images and amulets, pointed to an existential crisis for the Thai state. Anticommunist legislation had been framed to defend the monarchy and Buddhism as well as the sovereign nation-state, and the sacredness of the image bearing this political message turned the anticommunist struggle into a holy war.

A year after the armed conflict with the CPT, yet another royal Buddha image was cast, in April 1966, which was nearly identical to the Wat Bowonniwet image. To the base of this image, known as the Phra Nawaratbophit, was affixed a small amulet, Phra Somdet Chitralada-the Buddha seated in meditation, designed by the king's own hand and known popularly as the Might of the Kingdom amulet (phra khrueang kamlang 
phaendin). The compound from which the amulet was stamped contained dried flowers from garlands that the citizenry had offered in homage to the Emerald Buddha in Bangkok when the king attended to change the image's seasonal robes, ashes from burned incense and candle wax from royal monasteries and lichen from sacred sites all over the country. Bits of every province in the land were embedded in the amulet, transforming the tiny object into a ritual map of the kingdom, the geo-body scaled down and compressed into a miniature.

To celebrate the king's talents and creative works, the amulet also contained paint from his canvases and resins and colours from his sailboat, for he was a keen sailor and had built many vessels with his own hands. Strands of the king's hair collected after it was cut were also fused into the compounded material (Chaidiaw and Chaiya 1998: 33-49; Natthaphon 2012: 108-9). The Might of the Kingdom amulet containing parts of the king's body and the fruits of his labours moulded into the base of the Phra Nawaratbophit image and ritually empowered was no mere representation or symbol of the king. The corporeal king and his person now dwelt within the object. From 1965 to 1970, limited editions of the tiny Might of the Kingdom amulet were produced and distributed to reward government officials, soldiers and police for their public service and loyalty to the Crown (Chaidiaw and Chaiya 1998: 1-116). Paying homage to this amulet was equivalent to paying homage to the king.

The Phra Nawaratbophit Buddha image was charged with a special mission. Small copies with the Might of the Kingdom amulet at its base were cast and distributed to each provincial capital in the kingdom, and protocols were prescribed for its public display. The dimensions of the portable image were small ( 40 centimetres high and 23 centimetres wide), enabling it to be carried by hand and thus easily transported. The image was to preside over ceremonies where its presence would not conflict with protocols for other Buddha images, and it was to be brought out whenever the king visited or stayed in the province. Local authorities had discretion to display the image for festivals and ceremonies. The first province to receive one of the portable images was Nong Khai, on the Mekong River bordering Laos, marking the frontline of the Indochina conflict unfolding to the east (Nop 2002: 34-5; Natthaphon 2012: 112-13).

The Phra Nawaratbophit image with the amulet at its base aimed to bind the monarch to his subjects, but another, quite different, version of its origins explains its inception. It had been a custom from ancient times, so 
it was said, that when the king visited one of the satellite states guarding the frontiers of the kingdom, he would present the local lord with a royal sword, a weapon that took the place of the king's 'eyes and ears' as he watched over his domain. The local ruler would use this weapon to punish or subdue enemies who threatened his own domain. When the local ruler was replaced, this royal sword would be returned to the king, who might or might not confer it on the successor. In March 1964, King Bhumibol determined that times had changed and royal swords in the hands of provincial governors were no longer required to defend the country and maintain order. Criminal law would now be used to subjugate rebels and insurgents. The king conceived the Phra Nawaratbophit as a replacement for the royal sword-a Buddha image that would seal his relationship with his subjects. Materials taken from every province were fused in the image, so prostration to pay respect to this Buddha image was tantamount to paying homage to all the sacred sites in the country (Nop 2002: 31-4).

The explanations of how the Phra Nawaratbophit image came to be cast at a time when the Thai state was embarking on a war with what it deemed to be an alien ideology seem light-years from the social life and environmental niche of the southern policeman's beloved Songkhla lakes. The Red Sword he had acquired from the noble family in Uttaradit was retired with him at the very moment the ninth Bangkok king and his advisers decided that this item of the royal regalia - an emblem of royal punishment and subjugation-needed to be replaced with the image of the Buddha challenged by Mara, the incarnation of evil. In response, the Buddha lowers his right hand and points downward, calling the Earth to witness that he is, indeed, the Buddha. The king wanted to modernise the symbolism of the royal sword traditionally given to local lords to punish wrongdoers and defend the kingdom by replacing it with a sacred image that was engaged in existential defence, a serene Buddha defying an enemy that was said to be threatening every corner of the realm.

Khun Phan retired in the mid-1960s at the time the king commissioned these images, and the Red Sword he had carried was wrapped in its cloth for the last time. He had desired the sword as soon as he was introduced to it and cherished it for the rest of his life- a weapon for punishment and for defence to accompany the 'Little Raja' title conferred on him by Muslims in Malaya after he carried out a successful mission in the late 1930s. The title, the sword and his Malay kris emboldened him. He sensed that his authority would be enhanced if he embraced the weapons of supralocal, sovereign rule, convincing him that he would not, and could not, be 
defeated. He had modern firearms, martial arts he used with deadly effect and he possessed talismans and rituals that could frighten an adversary or spook a lawbreaker who dared to venture into the province he protected.

Aspects of Khun Phan's life, such as his lifelong quest for saiyasat knowledge and his observance of its regimens, hark back to an earlier age in Thailand. The writ of central government stopped at the edge of the village and people relied on local forms of security unregulated by institutional constraints. The saiyasat magic that he cultivated belongs to an underdeveloped rural sector that no longer exists in an age when villagers have mobile phones and access to the internet. The countryside had been absorbed into a royal state rejuvenated by a young, still untested monarch and his advisers. The scope for a single rural policeman to exercise his magical powers, intimidation and surveillance narrowed as authority and power moved gradually from the periphery to the centre.

National history has little place, perhaps no place, in its narrative for such a figure. The southern policeman is too small and his reputation too darkened by violence. He can be a hero to local people but not a hero in the national story. Readers wanting to understand a complex past yearn for big paradigms or large-scale tragedies such as the humiliation of an indigenous ruler by Western colonial powers, rather than the bruising encounters between the police and outlaws in the remote Thai countryside in the first half of the twentieth century. Khun Phan's willingness to trade life for life, as he did when he set free Suea Dam after the outlaw surrendered one of his men to certain death, does not fit into bigparadigm history. That incident barely makes it into the historical record, partly because the evidence to corroborate it is slim and partly because the sacrifice of such a man's life is not ennobling. The episode fits neither the grand narrative of tragedy nor the grand narrative of romance. A social history built around a biographical study of a provincial policeman whose accomplices disrespected human remains by leaving the corpses of men they had killed for days in the tropical sun is a microhistory for which it is awkward to find a place in national history.

Khun Phan's record of arresting lawbreakers, and sometimes killing them with his police team when they refused to surrender and preferred to fight to the death, stands out in the annals of Thai police history. Some of his actions were brutish and shocking by any measure, yet in the police culture at the time they were worthy of only moderate disciplinary action. His ruthless methods were popular in communities beset by violence and 
crime. At the same time, he epitomises the emotional significance that attaches to the police, who stir in the Thai citizenry anxiety and fear, notwithstanding the fraternisation and rapport that draw citizens to police in the communities they serve and that make possible peaceable policing. The aura of apprehension surrounding the police runs like an iridescent thread through the life and times of Khun Phan.

Details of Khun Phan's police operations that illustrate his willingness to use the power to punish are unsettling and, as I read through the accounts, I thought about what the Australian historian Greg Denning once said about the need for history of the Aboriginal people. 'For me', said Denning,

the dead and the living need history. The dead need history for the voice it gives them. The living need history, not to be made to feel guilty for a past they are not responsible for or cannot change. The living need a history disturbing enough to change the present. (Denning 1998: 4-5)

Denning's sentiments do not apply to the southern policeman in all respects. In the last decades of his life, Khun Phan had so much to say about himself that has found its way into books and into community memory that he hardly needs another biographer to give him voice. It is the last sentence in Denning's comment that fits the policeman's case. The disturbing history that Khun Phan made needs to be kept alive in present knowledge. 
This text is taken from Power, Protection and Magic in Thailand: The Cosmos of a Southern Policeman, by Craig J. Reynolds, published 2019 by ANU Press, The Australian National University, Canberra, Australia. 